\title{
Nursing empathy and prosociality: The relationship
}

\author{
José María Galán González-Serna \\ 1. Centro Universitario de Enfermería San Juan de Dios \\ 2. Universidad de Sevilla (España)
}

\begin{abstract}
The psychological and ethical theories affirm that the empathy favors the prosocial behavior. Objetives: We hypothesized that the evaluation of the axiological estimate of professional values gives us indirect data regarding the ethical motivations of the prosocial behavior. Method: An observational, transverse, descriptive study was carried out with a sample of 188 professional and students of Nursing. This paper aims to describe in the sample selected, the result of applying the Professionals Ethical Values Scale as well as the scores of dimensions of empathy reached by Interpersonal Reactivity Index (IRI) and to analyze if there is a statistical relationship between the four variables of empathy of IRI scale and the results of Professionals Ethical Values Scale. Descriptive variables were calculated. It was applied normality test of Kolmogorov-Smirnov and the Shapiro-Wilk test. Finally were calculated the correlation between variables with Spearman's Rho test. Results: The values of abnegation and altruism were not among the highest rated. A statistically significant relationship was obtained between three dimensions of empathy and the result of the estimation of professional ethical values by nurses and nursing students. Discussion: The results suggest that there seems to be a significant relationship between empathy and prosociality, which agrees with the theoretical constructs that explain human moral development. This relationship has to be checked with new research.
\end{abstract}

Keywords: empathy; ethics; altruism; education; nursing; professionalism

\section{Introduction}

Prosocial behavior consists of any behavior that benefits others or that has positive social consequences and is performed voluntarily ${ }^{[1]}$. Prosocial actions may be motivated by empathy and concern for the well-being and rights of others, as well as for selfish or practical interests ${ }^{[2]}$.

For its part, empathy is a complex, multi-dimensional concept that has moral, cognitive, emotive and behavioural components $^{[3]}$.

Health professionals, by the very nature of their work, must engage in prosocial behavior that may be based on altruism or reciprocity ${ }^{[4]}$. Empathy is considered as a fundamental value in nursing care, which allows us to understand the patient's emotions and know how to manage them effectively, responding to their needs ${ }^{[5,6]}$. Eisenberg ${ }^{[7]}$ links the development of moral judgment with the empathic capacity, which she considers essential for the achievement of mature and supportive social behaviors.

In the last two decades of the twentieth century, there has been an increasing interest in empirically demonstrating a statistically positive relationship between empathy and prosocial behavior ${ }^{[8-15]}$ and a negative relation (or no relationship)

Copyright (C) 2018 José María Galán González-Serna

doi: 10.18686/jn.v7i1.129

This is an open-access article distributed under the terms of the Creative Commons Attribution Unported License

(http://creativecommons.org/licenses/by-nc/4.0/), which permits unrestricted use, distribution, and reproduction in any medium, provided the original work is properly cited. 
between personal unrest and prosocial behavior, both in adults and children ${ }^{[16,17]}$. Thus, empathy with the suffering of others favors altruistic acts and limits personal aggression ${ }^{[10,18-22]}$.

The estimation of ethical values seems to be positively influenced by the degree of empathy and the development of empathy is employed to stimulate moral maturity in childhood and adolescence ${ }^{[23]}$. Thus empathy is likely to influence the axiological estimate of professional values. We hypothesized that the evaluation of the axiological estimate of professional values gives us indirect data regarding the ethical motivations of the prosocial behavior.

This paper aims to describe in the sample selected the variables Axiological Estimation of Professional Ethical Values as well as the Dimensions of Empathy proposed by Davis and to analyze if there is a statistical relationship between the four variables of empathy of the IRI scale and the Axiological Ethical Professionals Values Scale.

\section{Material and method}

An observational, transverse, descriptive and analytical study was carried out. The study was carried out in students of the first two years of the nursing degree and nursing professionals of institutions of the Hospital Order of San Juan de Dios in Seville (Spain). It was a cross-sectional study whose data collection was conducted from April 2011 to October 2013. The unit of analysis was a sample of 188 (100\%) cases of which 101 (53.7\%) were students of the Nursing degree in the San Juan de Dios University Nursing Center and 87 (46.3\%) are professional nurses from the San Juan de Dios Hospitals in Seville, Spain. The number of students represented almost $100 \%$ of those enrolled while the number of nurses represented $30 \%$ of the possible. The variables included in the study were sociodemographic (age, sex, professional experience), the dependent variables were the Ethical Professionals Values Scale. The independent variables were the dimensions of Empathy according to IRI: Perspective (PT), Fantasy (FS), Empathic Concern (EC), Personal Distress (PD).

The instruments of measurement were two surveys:

1. Professionals Ethical Values Scale (PEVS). It is a self-made survey. The values survey has been published and in order to construct it, the values of the medical, nursing, physiotherapy, podology and psychology professions were identified, reviewing the different Spanish codes of ethics. With all the values identified in each code of ethics, a Likert intensity-type attitude survey was designed with 30 items, in which the respondent is requested, after obtaining their informed consent, to give their opinion on two questions about each of the values. In the first place, the professional is asked if he considers the value questioned as obligatory "always". This question explores whether the practitioner understands that the value proposed is inherent to his or her profession and should therefore be enforceable. The variable that generates is qualitative dichotomous (yes/no). Secondly, he is asked to quantify the degree of importance assigned to each value to achieve the goals of their professional practice. For this we asked to score from 0 to 7 and indicated that the answer 0 means that the value is not important at all, answer 7 means that the value is quite important and answers 1 to 6 assign a degree of importance.

2. Interpersonal Reactivity Index (IRI) (Davis, 1980, 1983) validated in Spain by Pérez-Albéniz, De Paul, Etxeberria, Montes and Torres (2003) and Mestre, Frías and Samper (2004). It is an easy-to-apply scale, consisting of 28 items divided into four subscales that measure four dimensions of the overall concept of empathy: Perspective (PT), Fantasy (FS), Empathic Concern (EC) and Personal Distress, with seven items each. The most outstanding characteristic of this instrument is that it allows to measure both the cognitive aspect and the emotional reaction of the individual when adopting an empathic attitude. The PT and FS subscales evaluate the most cognitive processes: The Score in Perspective indicates the spontaneous attempts of the subject to adopt the perspective of the other to real situations of daily life, that is, the ability to understand the point of view of the another person. The Fantasy subscale evaluates the 
tendency to identify with characters of the cinema and of literature, that is, the imaginative capacity of the subject to put itself in fictitious situations. The Empathy (EC) and Discomfort or Personal Distress (DP) subscales measure the emotional reactions of people to the negative experiences of others: in the first (EC) the feelings of compassion, concern and affection are measured in the face of discomfort of others (these are "other-oriented" feelings), the second (PD) evaluates the feelings of anxiety and discomfort that the subject manifests by observing the negative experiences of others (these are "ego-oriented" feelings). This scale has been adapted to Spanish, replicating the results found by Davis in the Anglo-Saxon sample (see Pérez-Albéniz et al., 2003). In both cases, the scale shows adequate psychometric properties, although it is true, as pointed out (Cliffordson, 2001), these properties are better in student samples than in adults. (Fernández-Pinto et al., 2008).

The information was collected through anonymous surveys conducted to first and second grade students and to nursing professionals, using the questionnaires described. The participation of students and professionals was voluntary and free, and data collection was anonymous, in order to completely safeguard participants' identity confidentiality. The study was approved by the Institutional Ethics Committee of the Hospitaller Order of San Juan de Dios.

Descriptive variables were calculated. It was applied normality test of Kolmogorov-Smirnov and the Shapiro-Wilk test. Finally were calculate the correlation between variables with Spearman's Rho test.

\section{Results}

Professional Ethical Value Scale

The ordinal qualitative variables that compose the axiological estimation survey are 30 and the following table presents the following statistics of these variables referred to the sample: the mean, standard error of the mean, standard deviation, median, mode, minimum, maximum, sum and percentiles 25 and 75.

\begin{tabular}{|c|c|c|c|c|c|c|c|c|c|c|}
\hline \multirow{2}{*}{ Ethical Value } & \multirow{2}{*}{ Mean } & \multirow{2}{*}{$\begin{array}{l}\text { Standard } \\
\text { Error of the } \\
\text { Mean }\end{array}$} & \multirow{2}{*}{$\begin{array}{l}\text { Standard } \\
\text { Deviation }\end{array}$} & \multirow{2}{*}{ Median } & \multirow{2}{*}{ Mode } & \multirow{2}{*}{ Minimun } & \multirow{2}{*}{ Maximun } & \multirow{2}{*}{ Sum } & \multicolumn{2}{|c|}{ Percentiles } \\
\hline & & & & & & & & & 25 & 75 \\
\hline \multicolumn{11}{|l|}{ Abnegation } \\
\hline Reception & 5.95 & 0.08 & 1.096 & 6 & 7 & 2 & 7 & 1119 & 5 & 7 \\
\hline $\begin{array}{l}\text { Personal } \\
\text { attention }\end{array}$ & 5.73 & 0.099 & 1.355 & 6 & 7 & 2 & 7 & 1077 & 5 & 7 \\
\hline Altruism & 4.37 & 0.132 & 1.783 & 5 & 5 & 0 & 7 & 800 & 3 & 6 \\
\hline Autonomy & 4.51 & 0.121 & 1.649 & 5 & 5 & 0 & 7 & 835 & 4 & 6 \\
\hline Benevolence & 5.89 & 0.085 & 1.172 & 6 & 7 & 2 & 7 & 1107 & 5 & 7 \\
\hline Quality & 5.28 & 0.114 & 1.555 & 5 & 7 & 0 & 7 & 987 & 4 & 7 \\
\hline Closeness & 5.68 & 0.085 & 1.166 & 6 & 7 & 2 & 7 & 1062 & 5 & 7 \\
\hline Fellowship & 6.12 & 0.071 & 0.971 & 6 & 7 & 3 & 7 & 1151 & 5 & 7 \\
\hline Compassion & 4.91 & 0.113 & 1.551 & 5 & 5 & 0 & 7 & 918 & 4 & 6 \\
\hline Competition & 5.55 & 0.086 & 1.172 & 6 & 5 & 2 & 7 & 1032 & 5 & 7 \\
\hline Confidentiality & 6.1 & 0.088 & 1.204 & 7 & 7 & 1 & 7 & 1147 & 5 & 7 \\
\hline Knowledge & 5.68 & 0.094 & 1.282 & 6 & 7 & 2 & 7 & 1051 & 5 & 7 \\
\hline Care & 6.01 & 0,074 & 1.016 & 6 & 7 & 1 & 7 & 1129 & 5 & 7 \\
\hline Diligence & 5.02 & 0.114 & 1.554 & 5 & 6 & 0 & 7 & 938 & 4 & 6 \\
\hline Efficiency & 5.43 & 0.098 & 1.331 & 6 & 7 & 1 & 7 & 1010 & 4 & 7 \\
\hline Empathy & 5.74 & 0.09 & 1.222 & 6 & 7 & 2 & 7 & 1067 & 5 & 7 \\
\hline Equity & 6.07 & 0.082 & 1.117 & 7 & 7 & 2 & 7 & 1135 & 5 & 7 \\
\hline
\end{tabular}




\begin{tabular}{|c|c|c|c|c|c|c|c|c|c|c|}
\hline Fidelity & 5.36 & 0.09 & 1.228 & 5 & 6 & 2 & 7 & 997 & 5 & 6 \\
\hline Honesty & 5.55 & 0.085 & 1.151 & 6 & 6 & 1 & 7 & 1016 & 5 & 6 \\
\hline Justice & 5.14 & 0,128 & 1.735 & 5 & 7 & 0 & 7 & 940 & 4 & 7 \\
\hline Prudence & 5.33 & 0.098 & 1.333 & 5 & 5 & 1 & 7 & 986 & 5 & 6 \\
\hline Respect Life & 5.69 & 0.097 & 1.327 & 6 & 7 & 0 & 7 & 1059 & 5 & 7 \\
\hline $\begin{array}{l}\text { Respect } \\
\text { Autonomy }\end{array}$ & 5.28 & 0.1 & 1.357 & 5 & 6 & 1 & 7 & 967 & 4 & 6 \\
\hline Responsibility & 5.86 & 0.087 & 1.179 & 6 & 7 & 2 & 7 & 1078 & 5 & 7 \\
\hline Simplicity & 5.02 & 0.108 & 1.467 & 5 & 5 & 0 & 7 & 924 & 4 & 6 \\
\hline Veracity & 5.01 & 0.111 & 1.5 & 5 & 5 & 0 & 7 & 911 & 4 & 6 \\
\hline Tolerance & 5.64 & 0.086 & 1.172 & 6 & 7 & 2 & 7 & 1054 & 5 & 7 \\
\hline $\begin{array}{l}\text { Correct } \\
\text { treatment }\end{array}$ & 5.84 & 0.087 & 1.191 & 6 & 7 & 3 & 7 & 1087 & 5 & 7 \\
\hline $\begin{array}{l}\text { Vocation } \\
\text { Serve }\end{array}$ & 5.32 & 0.111 & 1.504 & 5 & 7 & 0 & 7 & 984 & 4 & 7 \\
\hline
\end{tabular}

Interpersonal Reactivity Index

The statistics have been obtained: Median, Asymmetry, Standard error of asymmetry, Curtosis, Range, Minimum, Maximum, Percentile $(25,50,75)$; and the Kolmogorov-Smirnov and Shapiro-Wilk tests were applied to evaluate the normality of the variables.

Table 2. Interpersonal reactivity index statistics

\begin{tabular}{|c|c|c|c|c|c|}
\hline & & PT & FS & EC & PD \\
\hline \multirow[b]{2}{*}{$\mathrm{N}$} & $\mathrm{V}$ & 188 & 188 & 188 & 188 \\
\hline & Lst & 0 & 0 & 0 & 0 \\
\hline Median & & 24 & 22 & 26 & 17 \\
\hline Asymmetry & & 0.304 & 0.307 & -0.064 & 0.01 \\
\hline Standard Error of asymmetry & & 0.177 & 0.177 & 0.177 & 0.177 \\
\hline Curtosis & & -0.569 & -0.247 & -0.994 & -0.65 \\
\hline Standard Error of curtosi & & 0.353 & 0.353 & 0.353 & 0.353 \\
\hline Range & & 19 & 24 & 17 & 22 \\
\hline Minimum & & 16 & 11 & 18 & 7 \\
\hline Maximum & & 35 & 35 & 35 & 29 \\
\hline \multirow{3}{*}{ Percentile } & 25 & 22 & 19 & 22 & 13 \\
\hline & 50 & 24 & 22 & 26 & 17 \\
\hline & 75 & 28 & 26 & 29 & 20 \\
\hline \multicolumn{2}{|l|}{ Kolmogorov-Smirnov } & $\begin{array}{c}P \\
<0,0001\end{array}$ & $\begin{array}{c}P \\
<0.0001\end{array}$ & $\begin{array}{c}P \\
<0.0001\end{array}$ & $\begin{array}{c}P \\
<0.0001\end{array}$ \\
\hline Shapiro-Wilk & & $P=0.001$ & $P=0.004$ & $\begin{array}{c}P= \\
0.0001\end{array}$ & $P=0.001$ \\
\hline
\end{tabular}

PT: perspective taking; FS: fantasy; EC: empathic concern; PD: personal distress

On the other hand, the relation of the four dimensions of empathy (PT-FS-EC-PD) with the estimation of the usefulness of the professional ethical value (PEVS) was studied.

When the Spearman Rho test was applied, statistically significant correlations were obtained between PEVS results and PT; EC; PD. The correlation between PEVS and FS is not statistically significant. 
Table 3. Rho de Spearman Between IRI and PVES

\begin{tabular}{|c|c|c|c|c|c|}
\hline & & PT & FS & EC & PD \\
\hline \multirow{3}{*}{$\begin{array}{l}\text { Axiological } \\
\text { estimate of } \\
\text { ethical values }\end{array}$} & $\begin{array}{l}\text { Correlation } \\
\text { coefficient }\end{array}$ & $0.378 * *$ & 0.082 & $0.424 * *$ & $-0.297 * *$ \\
\hline & Sig. (bilateral) & 0 & 0.263 & 0 & 0 \\
\hline & $\mathrm{N}$ & 188 & 188 & 188 & 188 \\
\hline
\end{tabular}

\begin{tabular}{|c|c|c|c|c|}
\hline Very Low & Low & Moderate & Appreciable & High \\
\hline$<0.300$ & $>0.290$ & $>0.390$ & $>0.490$ & $>0.590$ \\
\hline
\end{tabular}

It turns out that a low and positive correlation is found between PVES and PT ( $\mathrm{r}=0.378$; $\mathrm{p}<0.0001)$; a moderate and positive correlation between PVES, and EC ( $\mathrm{r}=0.424 ; \mathrm{p}<0.0001)$; a low and negative correlation between PVES and PD $(r=-0.297 ; p<0.0001)$. No correlation was found between PVES and FS $(r=0.263 ; p=0.263)$.

\section{Discussion}

According to the international scientific literature, relation between values and moral emotions has been studied very little. The causal relation between values and emotional tendencies is not entirely clear. However, there are theoretical reasons to expect that values and moral emotions are related, and therefore research of the topic would enhance our understanding of the nature of moral motivation ${ }^{[23]}$.

In this research it is relevant to find that most of the professional ethical values evaluated in this sample reach a high mean scale score, however the altruism score gets an average grade score and the self-abnegation result scores below the mean. The lowest score of these two values, that can be considered especially prosocial with respect to the other values, seems logical in a group of professionals and students since the nursing professional usually seeks a reward for his work beyond that his attitude is open to help patients with some altruism or with some self-denial[24].

On the other hand, it is relevant that a statistically significant correlation was obtained with some dimensions of empathy. Above all, a positive correlation of a moderate degree with the "Empathic Concern" (EC), which measures feelings of compassion, concern, and affection for the discomfort of others (these are "other-oriented" feelings) under the "Taking of perspective" (PT) that indicates the spontaneous attempts of the subject to adopt the perspective of the other to real situations of daily life, that is, the ability to understand the other person's point of view. On the other hand, the correlation was negative of low degree regarding the dimension "Personal Distress" (PD) The Personal Distress score assesses the feelings of anxiety and discomfort that the subject manifests when observing the negative experiences of the others (it is about "self-oriented" feelings).

In relation to our findings, especially regarding the role that the empathic concern seems to have on the estimation of prosocial values, Pohling R et al. found an important role of affective empathy, in particular "Empathic concern", with regard to personal values and ethical competence ${ }^{[25]}$. Silfver $\mathrm{M}$ et al. in their study named "The relation between value priorities and proneness to guilt, shame, and empathy" found that values explained less variance in "Personal distress" than in "Empathic concern" or "Perspective-taking"[23]. Duarte J et al found that "Empathic concern" was positively associated with compassion satisfaction as well as with compassion fatigue in nurses ${ }^{[26]}$. Persons $\mathrm{BN}$, 
reported that only emotional empathy, not cognitive empathy, accounted for up to $18 \%$ additional variance in altruistic values, which further confirmed the emphasis on feelings, as postulated by the empathy-altruism hypothesis ${ }^{[27]}$.

Among the limitations of this work we must indicate the type of sample obtained by convenience and in a specific population, in the south of Spain. The internal validity of the results, in principle, will be adequate with respect to the field of study and the external validity will be limited as it is not a representative sample of the general population. New research should be done by expanding the population and using random samples to confirm the findings.

The results suggest that there seems to be a significant relationship between empathy and prosociality, which agrees with the theoretical constructs that explain human moral development.

The relationship between professional ethical nursing values and empathy should be studied more extensively because of this relationship it is possible to deduce new strategies for the moral development of nurses and nursing students

\section{Reference}

1. Eisenberg N, Fabes RA, Spinrad TL, 2007, Prosocial development. Handbook of Child Psychology.

2. Santrock JW, 2007, A topical approach to life span development. 4th Ed. McGraw-Hill, New York, 489-491.

3. Morse J, Anderson G, Botter J, et al., 1992, Exploring empathy: a conceptual fit for nursing practice? Image-the journal of nursing scholarship, vol. 24(4): 273-280.

4. Brown SL, Cialdini RB, 2015, Funtional motives and funtional consecuences of prosocial behavior. In Schroeder DA, Graziano G, 2015, The Oxford HandBook of Prosocial Behavior. Oxford University Press, 346-361.

5. Cortina A, 1997, Las claves de la ética sanitaria [Spanish]. The keys to health ethics. Arroyo MP, Cortina A, Torralba MJ, Zugasti J(editors). Ética y legislación en enfermería. McGraw-Hill Interamericana, Madrid.

6. Falcó Pegueroles A, 2005, Cuidar siguiendo los valores y principios éticos propios de la enfermería [Spanish]. Caring for the values and ethical principles of nursing. Enfermería Clínica, vol.15(5): 287-290.

7. Eisenberg, N, 2000, Emotion, Regulation and moral development. Anual Review of Psychology, vol.51(51): 665-697.

8. Batson D, Batson J, Slingsby J, Harrell K, Peekna H, 1991,Todd M. Empathic joy and the empathy-altruism hypothesis, Journal of Personality and Social Psychology, vol. 61(3): 413-426.

9. Hoffman LM , 1987, La aportación de la empatía a la justicia y al juicio moral [Spanish]. The contribution of empathy to justice and moral judgment. En N. Eisenberg y J. Strayer (editors), La empatía y su desarrollo. Desclée de Brouwer, Bilbao, 59-93.

10. Hoffman ML, 1990, Empathy and justice motivation. Motivation and Emotion, vol.14 (2): 151-172.

11. Bandura A, Barbaranelli C, Caprara GV, Pastorelli C, 1996, Mechanisms of moral disengagement in the exercise of moral agency. Journal of Personality and Social Psychology, vol.77(2): 364-374.

12. Caprara GV, Pastorelli C, 1993, Early emotional instability, prosocial behavior, and aggression: Some methodological aspects. European Journal of Personality, vol.7: 19-36.

13. Fuentes MJ, Apodaka P, Etxebarría I, Ledesma AR, López F, Ortiz MJ, 1993, Empatía, role-taking y concepto de ser humano como factores asociados a la conducta prosocial-altruista [Spanish]. Empathy, role-taking and the concept of being human as factors associated with prosocial-altruistic behaviour. Infancia y Aprendizaje, vol. 61: 73-87.

14. López F, Apodaka, P, Eceiza A, Etxebarría F, Fuentes MJ, Ortiz MJ, 1994, Para comprender la conducta altruista [Spanish]. To understand the altruistic behavior. Edit. Verbo Divino, Navarra.

15. Ortiz MJ, Apodaca P, Etxebarría I, Ezeiza A, Fuentes MJ, López F, 1993, Algunos predictores de la conducta prosocial-altruista en la infancia: empatía, toma de perspectiva, apego, modelos parentales, disciplina familiar e imagen del ser humano [Spanish]. Some predictors of prosocial-altruistic behavior in childhood: empathy, perspective, attachment, parental models, family discipline and the image of the human being. Revista de Psicología Social, vol.8: 83-98.

16. Davis MH, 1983, Measuring individual differences in empathy: Evidence for a multidimensional approach. Journal of Personality and Social Psychology, vol.44(1): 113-126.

17. Carlo G, Raffaelli M, Laible DJ, Meyer KA, 1999, Why are girls less physically aggressive than boys? Personality and parenting mediators of physical aggression. Sex Roles, vol.40 (9/10): 711-729.

18. Hoffman LM, 1987, La aportación de la empatía a la justicia y al juicio moral [Spanish]. The contribution of empathy to justice and moral judgment. En N. Eisenberg y J. Strayer (editors), La empatía y su desarrollo. Desclée de Brouwer, Bilbao, 59-93. 
19. Hoffman ML, 1989, Empathic emotions and justice in society. Social Justice Research, vol. 3(4): 283-311.

20. Bandura A, 1987, Pensamiento y Acción. Edit. Martínez Roca, Barcelona.

21. Batson CD, Coke JS, 1981, Empathy: A source of altruistic motivation for helping? L.E.A, New Jersey.

22. Sobral J, Romero E, Luengo A, Marzoa J, 2000, Personalidad y conducta antisocial: Amplificadores individuales de los efectos contextuales. Psicothema, vol.12 (4): 661-70.

23. Silfver M, Helkama K, Lönnqvist J, Markku Verkasalo, 2008, The relation between value priorities and proneness to guilt, shame, and empathy. Motivation and Emotion, vol.32(2): 69-80.

24. Mestre Escrivá MV, Samper García P, Frías Navarro MD, 2002, Procesos cognitivos y emocionales predictores de la conducta prosocial y agresiva: La empatía como factor modulador [Spanish]. Cognitive and emotional processes predictors of prosocial and aggressive behavior: Empathy as a modulating factor. Psicothema, vol.14(2): 227-232.

25. Pohling R, Bzdok D, Eigenstetter M, Stumpf S, Strobel A, 2016, What is ethical competence? The role of empathy, personal values, and the five-factor model of personality in ethical decision-making. The Journal of Business Ethics, vol.137: 449-474

26. Duarte J, Pinto-Gouveia J, Cruz B, 2016, Relationships between nurses' empathy, self-compassion and dimensions of professional quality of life: A cross-sectional study. International Journal of Nursing Studies, vol.60: 1-11

27. Persons BN, Kajonius PJ, 2016, Empathy and universal values explicated by the empathy-altruism hypothesis. The Journal of Social Psychology, vol.156(6): 610-619 